\title{
Hereditary inclusion body myopathy: a clinical and genetic review
}

\author{
Miopatia com corpos de Inclusão hereditária: revisão clínica \\ e genética
}

\author{
Miopatía por cuerpos de inclusión hereditária: revisión \\ clínica y genética
}

\author{
Paulo Victor Sgobbi de Souza ${ }^{1}$, Bruno de Mattos Lombardi Badia ${ }^{1}$, \\ Eduardo Augusto Gonçalves ${ }^{1}$, Igor Braga Farias ${ }^{1}$, Wladimir Bocca \\ Vieira de Rezende Pinto ${ }^{2}$, Acary Souza Bulle Oliveira ${ }^{3}$
}

\begin{abstract}
1.MD, Division of Neuromuscular Diseases, Department of Neurology and Neurosurgery, Federal University of São Paulo (UNIFESP), São Paulo-SP, Brazil.

2.MD, MSc, Division of Neuromuscular Diseases, Department of Neurology and Neurosurgery, Federal University of São Paulo (UNIFESP), São Paulo-SP, Brazil.

3.MD, PhD, Division of Neuromuscular Diseases, Department of Neurology and Neurosurgery, Federal University of São Paulo (UNIFESP), São Paulo-SP, Brazil.
\end{abstract}

\begin{abstract}
Resumo
Introdução. Miosite com corpos de inclusão representa a miopatia adquirida mais comum na prática clínica de início após os 50 anos. Apesar da abordagem clássica de tal miopatia como condição clínica inflamatória, a base degenerativa muscular é considerada atualmente o principal mecanismo ligado a tais miopatias vacuolares. Formas hereditárias, embora raras, representam um grupo em expansão e pouco reconhecido na prática clínica. Objetivo. realizar revisão estruturada da literatura atual a respeito das formas hereditárias de miopatia com corpos de inclusão. Método. revisão das bases de dados da U.S. NLM PubMed e MEDLINE para análise de artigos originais, relatos de casos, series de casos e artigos de revisão incluindo os termos-chave "inclusion body myositis" OR "inclusion body myopathy" AND "genetics" OR "hereditary". Resultados. Este manuscrito oferece amplo artigo de revisão da literatura a respeito dos principais aspectos clínicos, de imagem, fisiopatológicos, genéticos e terapêuticos relacionados a miopatias hereditárias ligadas a 7 apresentações clínicas e genéticas diferentes (GNE, MATR3, VCP, SQSTM1, MYH2, HNRNPA2B1 e HNRNPA1). Conclusão. Miopatia com corpo de inclusão hereditária se associa atualmente a pelo menos 7 formas clínico-genéticas monogênicas distintas.
\end{abstract}

Unitermos. Miopatia com corpos de inclusão; neurogenética; miopatia vacuolar; miosite

\begin{abstract}
Introduction. Inclusion body myositis represents the most common acquired myopathy in clinical practice in patients over 50 years old. Despite classical approach to this myopathy as an inflammatory disorder, a muscle degenerative disorder is now considered the main mechanism linked to these vacuolar myopathies. Hereditary presentations, although quite rare, represent an expanding and underrecognized group in clinical practice. Objective. perform a structured review of the current literature regarding hereditary inclusion body myopathies. Method. review of U.S. NLM PubMed and MEDLINE database of original articles, case reports, case series and review articles including the terms "inclusion body myositis" OR "inclusion body myopathy" AND "genetics" OR "hereditary". Results. We present in this article a wide review regarding the main clinical, imaging, pathophysiological, genetic and therapeutic aspects related to hereditary myopathies linked to seven different clinical and genetic presentations (GNE, MATR3, VCP, SQSTM1, MYH2, HNRNPA2B1 and HNRNPA1). Conclusion. Hereditary inclusion body myopathy is associated with at least 7 distinct clinic and genetic monogenic forms.
\end{abstract}




\begin{abstract}
Resumen
Introducción. Miosite com corpos de inclusão representa a miopatia adquirida mais comum na prática clínica de início após os 50 anos. Apesar da abordagem clássica de tal miopatia como condição clínica inflamatória, a base degenerativa muscular é considerada atualmente o principal mecanismo ligado a tais miopatias vacuolares. Formas hereditárias, embora raras, representam um grupo em expansão e pouco reconhecido na prática clínica. Objetivo. realizar revisão estruturada da literatura atual a respeito das formas hereditárias de miopatia com corpos de inclusão. Método. revisão das bases de dados da U.S. NLM PubMed e MEDLINE para análise de artigos originais, relatos de casos, series de casos e artigos de revisão incluindo os termos-chave "inclusion body myositis" OR "inclusion body myopathy" AND "genetics" OR "hereditary". Resultados. Este manuscrito oferece amplo artigo de revisão da literatura a respeito dos principais aspectos clínicos, de imagem, fisiopatológicos, genéticos e terapêuticos relacionados a miopatias hereditárias ligadas a 7 apresentações clínicas e genéticas diferentes (GNE, MATR3, VCP, SQSTM1, MYH2, HNRNPA2B1 e HNRNPA1). Conclusão. Miopatia com corpo de inclusão hereditária se associa atualmente a pelo menos 7 formas clínico-genéticas monogênicas distintas.
\end{abstract}

Palabras clave. Miopatia com corpos de inclusão; neurogenética; miopatia vacuolar; miosite

Research developed in Universidade Federal de São Paulo, São Paulo-SP, Brasil.

\title{
INTRODUCTION
}

Inflammatory myopathies represent the main group of acquired myopathies in clinical practice with well-established clinical, laboratorial, imaging and therapeutical aspects related to idiopathic and paraneoplastic polymyositis and dermatomyositis ${ }^{1}$. Despite its designation and classification as an inflammatory myopathy by most authors in the past ${ }^{1}$, Inclusion body myopathy or myositis (IBM) has been progressively recognized as a chronic degenerative muscle disease $^{2,3}$. The frequent changes regarding pathophysiological processes ${ }^{4-6}$, the absence of clinical response to a definite specific therapeutic approach 7,8 and the recognition of new sporadic and hereditary clinical 
presentations $^{1,9,10}$ are disclosing several heterogeneous facets about IBM complexity.

Sporadic IBM (sIBM) represents the main acquired myopathy in patients over the age of 50 years, being frequently underdiagnosed, especially in the early stages of clinical compromise in which there is a clear predominance of selective weakness in long flexors of the fingers and forearms and quadriceps femoris before progression to scapular girdle, lower limb distal groups and bulbar regions ${ }^{4,10,11}$. There are well-established clinico-pathological diagnostic criteria described by the European Neuromuscular Centre in $2011^{5}$ which are currently used to diagnose sIBM with clinical and research purposes.

A complex association of pathophysiological processes occur in sIBM involving abnormal muscle autophagic mechanisms, nitric oxide and class I MHC (major histocompatibility complex) pathway-induced cellular stress responses, prolonged inflammation, proteostasis defects with diverse protein aggregates accumulation, and excessive release of proinflammatory cytokines (highlighting gammainterferon and interleukin-1 $\beta)^{1}$. There is no doubt that individual or familial genetic predisposing factors are involved in SIBM pathophysiology, including polymorphisms in several genes (including $\mathrm{NOTCH4}$ ) and in different components of the major histocompatibility complex ${ }^{4,8,12}$. As the only therapeutic approach with well-documented efficacy and safety, intravenous immunoglobulin has been used with partial benefit in cases of IBM with dysphagia?. 
Even though sharing some features with sIBM, atypical and heterogeneous clinical early-onset presentations with some distinct pathological features and new neurogenetic patterns, eventually familial, have been described in the last decade and characterize hereditary IBM (hIBM). In this perspective, it has become complex the comprehension of clinical, pathophysiological, radiological and genetic aspects associated with such hereditary myopathies and a wide clinical and genetic review of these new presentations is extremely necessary and presented herein.

\section{METHOD}

Looking for a wide review of the current knowledge on the clinical and genetic presentation of hIBM, a wide review of the literature was performed using a structured search in the database of article citations for medical and biomedical current literature from PubMed/MEDLINE and PubMed Central (PMC) (U.S. Department of Health and Human Services, U.S. National Institutes of Health-NIH biomedical research agency, National Center for Biotechnology Information-NCBI, U.S. National Library of Medicine) database, based on MeSH (Medical Subject Heading) vocabulary used for indexing article propose. The used terms in search included "inclusion body myositis" (introduced in 1996 in $\mathrm{MeSH}$ ) and "inclusion body myopathy" (introduced in 2010 and 2012 in $\mathrm{MeSH}$ ), including autosomal dominant or recessive inherited presentations. The search strategy used included all case reports, case series, review and 
original articles involving: (i) (inclusion body myositis) AND (hereditary); (ii) (inclusion body myositis) AND (genetics); (iii) (inclusion body myopathy) AND (hereditary). Search strategies were updated until $10^{\text {th }}$ July, 2020, and included studies since the first description of SIBM in 1971. All genetic presentations observed were individualized and carefully evaluated and the authors personal experience (including photos and videos from examination studies) was included to improve clinical characterization.

\section{RESULTS AND DISCUSSION}

The strategy used in the referred database searching engine provided 1899 distinct manuscripts during the described period for "inclusion body myositis", including 510 review manuscripts, 11 systematic review, 323 case reports and 20 randomized controlled trials. The strategy including "genetics" restricted 641 articles (293 in the last decade), involving 170 review manuscripts, 81 case reports and 2 systematic reviews. Instead of "genetics", the same strategy with "hereditary" brought, since the first result in 1980, 164 results (48 in the last decade), involving 35 reviews and 28 case reports. Using the new proper nomenclature "inclusion body myopathy" and "genetics" in the search resulted 306 results (with 115 in the last decade), including 62 reviews, 60 case reports and 1 systematic review. There was overlap of 365 manuscripts using the referred group strategies and unappropriated manuscripts were also excluded due to low quality of descriptions (i.e. genetic methods, absence of 
definite diagnosis, presence of polymorphisms or variants of uncertain significance, conclusion not properly supported by the results, cases with familial SIBM or with confusing classification between SIBM, familial SIBM and hIBM), leading to a final number of 63 studies of interest for this review purposes.

\section{Hereditary Inclusion Body Myopathy (hIBM)}

Classification and genetic basis of hereditary Inclusion body myopathy (hIBM)

The main current classification regarding hIBM correlates the major genetic presentations associated with autosomal dominant or recessive inheritance pattern and histopathological features with intracytoplasmic or intranuclear tubulo-filamentous inclusions. There are different clinical and genetic forms of hIBM (Table 1), mainly represented by GNE-related disorders (Nonaka distal myopathy, former hIBM type 2), VCP-associated disorders (former chromosome 9-related hIBM or multisystem proteinopathy type 1), HNRPA2B1 gene mutations (former multisystem proteinopathy type 2), SQSTM1 gene mutations, HNRNPA1 gene mutations (former multisystem proteinopathy type 3), and $M Y H 2$ gene mutations (former hIBM type 3 or chromosome 17 -related hIBM) ${ }^{13-19}$. This complex and heterogeneous genetic basis correlates with complex pathophysiological mechanisms in hIBM (Figure 1). 


\begin{tabular}{|c|c|c|c|}
\hline $\begin{array}{l}\text { Nomenclature } \\
\text { (hIBM type) }\end{array}$ & $\begin{array}{c}\text { Gene } \\
\text { (inheritance; } \\
\text { locus) }\end{array}$ & $\begin{array}{c}\text { Clinical and } \\
\text { pathological hallmarks }\end{array}$ & $\begin{array}{l}\text { Other systemic and } \\
\text { neurodegenerative } \\
\text { allelic disorders }\end{array}$ \\
\hline $\begin{array}{c}\text { Nonaka distal } \\
\text { myopathy (GNE- } \\
\text { related } \\
\text { disorders; hIBM } \\
\text { type 2) }\end{array}$ & $\begin{array}{l}\text { GNE (AR; } \\
\text { 9p13.3) }\end{array}$ & $\begin{array}{l}\text { Starting in the third to } \\
\text { fourth decade; distal and } \\
\text { symmetrical in the legs; } \\
\text { quadriceps-sparing } \\
\text { myopathy phenotype; } \\
\text { moderate/severe } \\
\text { proximal compromise of } \\
\text { the lower limbs and } \\
\text { Iliopsoas }\end{array}$ & $\begin{array}{l}\text { Allelic to AD Sialuria } \\
\text { (French type) }\end{array}$ \\
\hline $\begin{array}{c}\text { IBMPFD1 } \\
\text { (chromosome 9- } \\
\text { related hIBM; } \\
\text { multisystem } \\
\text { proteinopathy } \\
\text { type 1) }\end{array}$ & $\begin{array}{l}\text { VCP (AD; } \\
9 p 13.3)\end{array}$ & $\begin{array}{l}\text { Starting in the third to } \\
\text { seventh decade; limb- } \\
\text { girdle proximal, VCP- } \\
\text { positive inclusions; one } \\
\text { third with early-onset } \\
\text { FTLD; early-onset PDB }\end{array}$ & $\begin{array}{c}\text { Allelic to familial ALS } \\
\text { type } 14, \text { hereditary } \\
\text { spastic paraparesis } \\
\text { (variant) and CMT type } \\
2 Y\end{array}$ \\
\hline $\begin{array}{c}\text { IBMPFD2 } \\
\text { (multisystem } \\
\text { proteinopathy } \\
\text { type 2) }\end{array}$ & $\begin{array}{l}\text { HNRNPA2B1 } \\
(\mathrm{AD} ; 7 \mathrm{p} 15.2)\end{array}$ & $\begin{array}{l}\text { Starting in the third to } \\
\text { fourth decade; } \\
\text { scapuloperoneal } \\
\text { phenotype; PDB; lower } \\
\text { motor neuron disease } \\
\text { (rare), FTLD (rare) }\end{array}$ & ------ \\
\hline $\begin{array}{c}\text { IBMPFD3 } \\
\text { (multisystem } \\
\text { proteinopathy } \\
\text { type 3) }\end{array}$ & $\begin{array}{c}\text { HNRNPA1 } \\
\text { (AD; } \\
12 \mathrm{q} 13.13)\end{array}$ & $\begin{array}{l}\text { Starting in the fourth to } \\
\text { fifth decade; slowly } \\
\text { progressive limb-girdle } \\
\text { phenotype, severe } \\
\text { involvement of Iliopsoas } \\
\text { and abdominal wall; PDB }\end{array}$ & $\begin{array}{l}\text { Allelic to familial ALS } \\
\text { type } 20\end{array}$ \\
\hline $\begin{array}{c}\text { SQSTM1- } \\
\text { associated hIBM }\end{array}$ & $\begin{array}{l}\text { SQSTM1 (AD; } \\
5 q 35.3)\end{array}$ & $\begin{array}{l}\text { Late-onset distal } \\
\text { myopathy with rimmed } \\
\text { vacuoles (TDP-43 and } \\
\text { SQSTM1 positive } \\
\text { inclusions), PDB }\end{array}$ & $\begin{array}{l}\text { Allelic to FTLD with ALS } \\
\text { type } 3, \text { PDB type } 3\end{array}$ \\
\hline $\begin{array}{l}\text { hIBM type } 3 \\
\text { (MYPOP; } \\
\text { chromosome 17- } \\
\text { related hIBM) }\end{array}$ & $\begin{array}{c}\text { MYH2 } \\
\left(\mathrm{AD} / \mathrm{AR}^{*} ;\right. \\
17 \mathrm{p} 13.1)\end{array}$ & $\begin{array}{c}\text { Infancy-onset proximal } \\
\text { myopathy (quadriceps } \\
\text { femoris, pectoralis major } \\
\text { and minor), congenital } \\
\text { joint contractures, } \\
\text { external } \\
\text { ophthalmoplegia, } \\
\text { rimmed vacuoles; } \\
\text { variable scoliosis and } \\
\text { ptosis }\end{array}$ & $\begin{array}{l}\text { Allelic to distal } \\
\text { arthrogryposis type } 5\end{array}$ \\
\hline $\begin{array}{c}\text { MATR3- } \\
\text { associated hIBM } \\
\text { (distal myopathy } \\
\text { type 2)** }\end{array}$ & $\begin{array}{l}\text { MATR3 (AD; } \\
5 q 31.2)\end{array}$ & $\begin{array}{l}\text { Distal myopathy with } \\
\text { vocal cord and } \\
\text { pharyngeal dysfunction }\end{array}$ & $\begin{array}{l}\text { Allelic to familial ALS } \\
\text { type } 21\end{array}$ \\
\hline
\end{tabular}

AD: autosomal dominant; ALS: amyotrophic lateral sclerosis; AR: autosomal recessive; CMT: CharcotMarie-Tooth disease; FTLD: frontotemporal lobar degeneration; IBMPFD: inclusion body myopathy with early-onset Paget disease of bone with or without frontotemporal dementia; PDB: Paget disease of bone; $*$ : in rare presentations; $* *$ : not described separately in the text. 
Figure 1. Pathophysiological mechanisms involved in the different hIBM subtypes. The abnormal formation of rimmed vacuoles and intracellular cytoplasmic aggregates depends on the existence of mutations in genes involved in different cell mechanisms: (1) abnormal sialic acid biosynthesis and disruption of sialyation (sialoglycoconjugation) and post-translational changes in intracellular proteins involved in basic homeostasis (i.e. GNE); (2) ubiquitin-proteasome system dysfunction; (3) abnormal mRNA metabolism processes and abnormal transcription; (4) abnormal autophagy and autolysosome formation; and (5) abnormal actinmyosin interaction and excitation-contraction coupling (i.e. $M Y H 2)^{19,21}$.

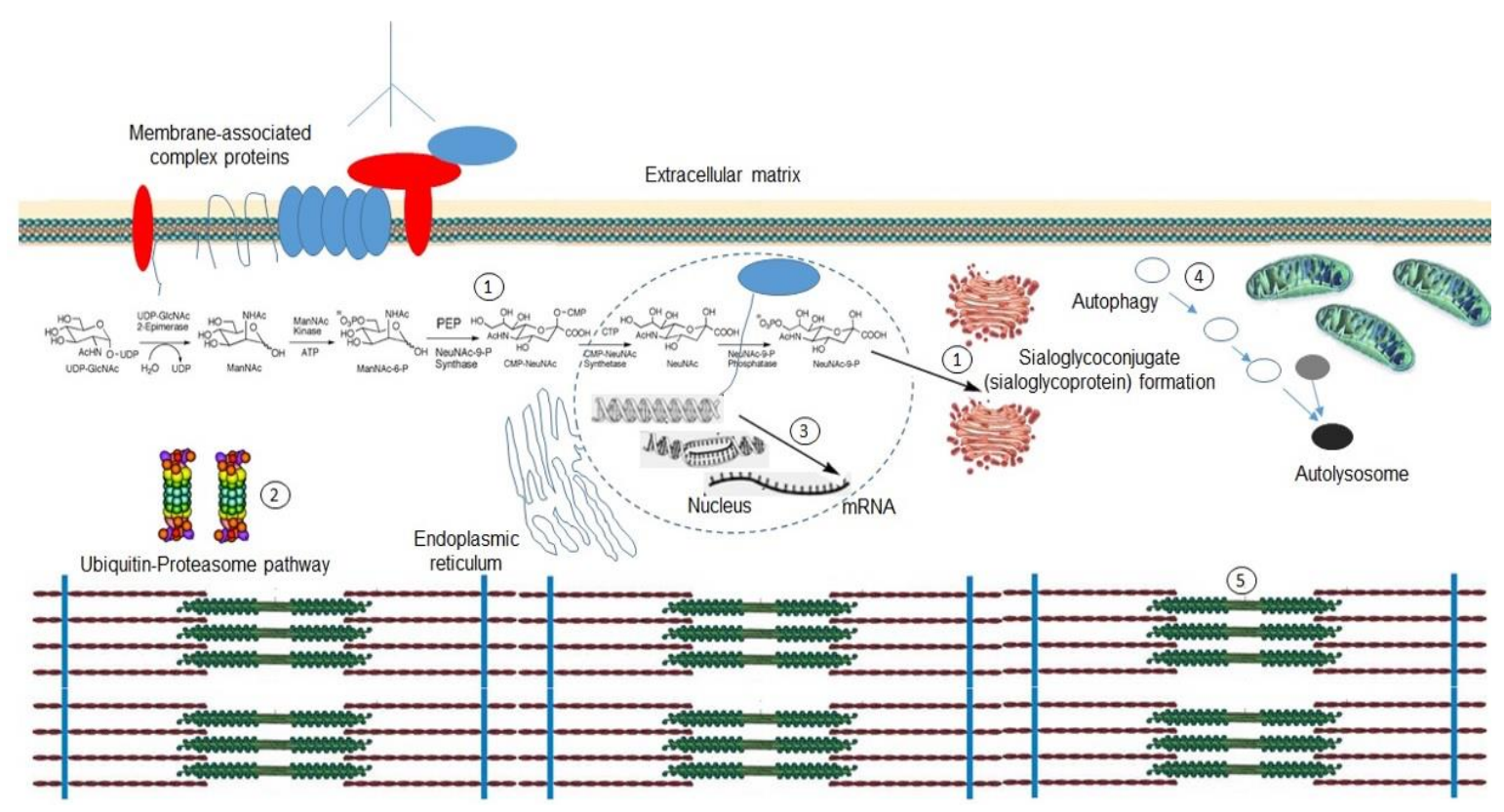

Also in the group of vacuolar myopathies with inclusion bodies, heterozygous mutations in MATR3 gene (5q31.2), typically associated with familial ALS type 21 and distal myopathy with vocal cord and pharyngeal dysfunction (former "distal myopathy type 2"), can present in some cases as IBM phenotype starting in the fourth to sixth decade of life with marked asymmetric involvement of the lower limbs, sparing the gastrocnemius, but also involving hand and shoulder girdle in asymmetrical pattern and bulbar dysfunction ${ }^{20}$. Some authors currently include MATR3related vacuolar myopathy as a cause of hIBM, while others 
prefer to classify this condition in the distal myopathy group. Classically included in the group of hIBM, the former autosomal dominant IBM type 1 (hIBM type 1 ), related to homozygous or compound heterozygous mutations in the $D E S$ gene (2q35), has been classified in the last few years in the group of myofibrillar myopathies (MM), being currently known as MM type 1 (MFM1), as a consequence of direct dysfunction of Z-disk structure by abnormal coding of desmin. However, many authors still classify desminopathies as a cause of hIBM due to the common presence of red rimmed vacuoles in myopathic fascicles $4,8,12-14,17,21$.

It is essential to differentiate hIBM from familial IBM (fIBM). Despite nomenclature represents a common final pathway in classification in some neuromuscular disorders, fIBM represents a definition limited to cases in which clinical and histopathological findings of sIBM occur in two or more patients from the same generation from a family or in cases with definite autosomal dominant inheritance pattern. Thus, there are different clinical and muscle histopathological patterns in fIBM when compared to hIBM $^{12}$. It has been welldescribed several familial aggregates of fIBM with genetic association with specific HLA (human leukocyte antigen) alleles, highlighting DR3 (DRB1*0301/0302) and DR15(2)/4 (DRB1*1502/0405), both which were previously described in cases of SIBM and not correlated with hIBM 4,12,21. 
In hIBM, as well as in sIBM, muscle pathology hallmark is the finding of rimmed vacuoles (authophagic vacuoles) (Figure 2), without immunoexpression of MHC class I in muscle fibers, without the presence of congophilic-positive amyloid deposits in vacuoles and without the presence of TCD8+ lymphocytes ${ }^{1,19}$. However, also as well as in SIBM, there are cases of hIBM in which there are no rimmed vacuoles, but rather the presence of a highly suggestive phenotype for hIBM diagnosis with the existence of chronic myopathic findings without necrosis and only mild lymphocytic infiltrate with ragged-red fibers (or ragged-blue fibers) in modified Gomori trichrome stain and negative staining for cytochrome c-oxidase expression, suggestive of the diagnosis of the some different subtypes of hIBM ${ }^{1,19}$.

Figure 2. Muscle pathology findings in hIBM associated with VCP gene mutations. Histopathological study disclosing rimmed vacuoles (white arrow) in hematoxylineosin $(A, B)$ and modified Gömöri trichrome staining (C,D) associated with moderate neurogenic changes with angulated fibers (white arrow-head) in NADH-TR staining (E). No marked inflammatory infiltration is observed. Source: first author own archive (reproduced with the patient's permission and informed consent).

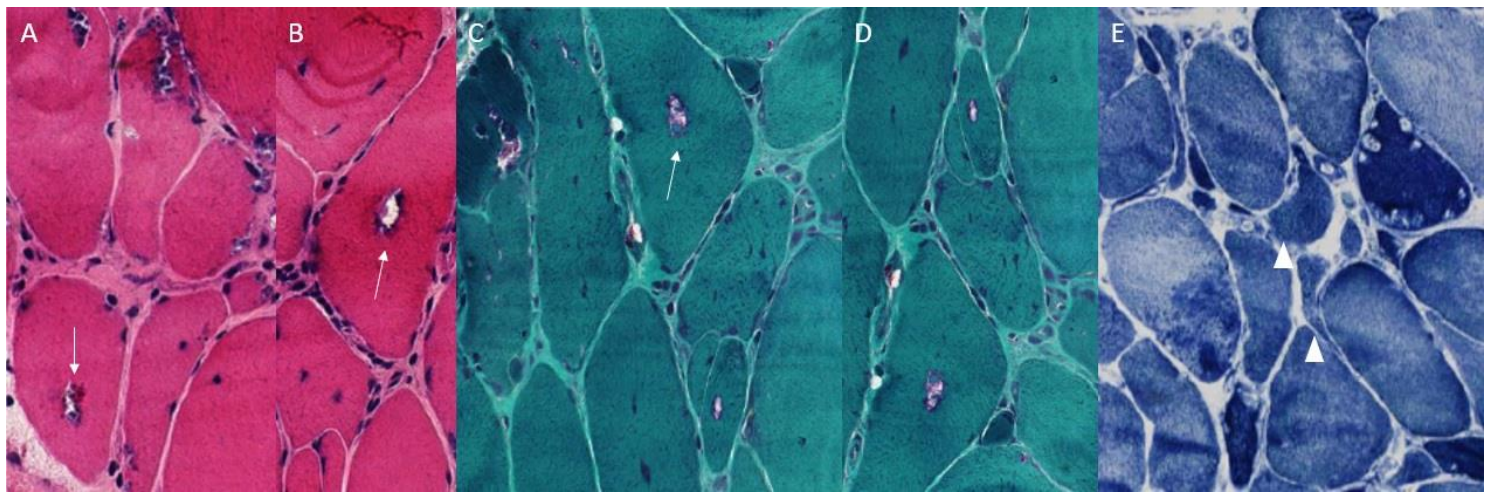


Inclusion body in rimmed vacuoles in hIBM exhibits a complex content of protein aggregates, such as in SIBM and in senile plaques in Alzheimer's disease, including betaamyloid, tau-hyperphosphorylated, presenilin-1, alphasynuclein, alpha1-antichemotrypsin, beta-amyloid precursor protein, p62 (sequestosome 1), TDP-43 (transactive response DNA-binding protein $43 \mathrm{kDa}$ ), apolipoprotein-E, gamma-tubulin, gelsolin, apoptosis regulatory proteins ( $\mathrm{BCl}$ 2, $\mathrm{BAX}, \mathrm{BCl}-\mathrm{x}$ ), oxidative stress proteins (including superoxide dysmutase), clusterin, prion protein, ubiquitin and proteosomal catalytic core proteins. It is essential to make differential diagnosis with other disorders which originate rimmed vacuoles, including oculopharyngeal muscular dystrophy, $\mathrm{X}$-linked Emery-Dreifuss muscular dystrophy, congenital muscular dystrophy with rigid spine syndrome, some forms of limb-girdle muscular dystrophies (including LGMD1A, LGMD1G and LGMD2G), some rare mutations in LAMA2 gene and chronic denervation (such as in spinal muscular atrophies and previous acute poliomyelitis) ${ }^{1,4,12}$. A summary of the main clinical, pathological, laboratorial and therapeutic aspects of SIBM and hIBM is presented in Table 2. 
Table 2. Practical comparison of clinical, pathological, laboratorial and therapeutic aspects between SIBM and hIBM $^{1,12}$.

\begin{tabular}{|c|c|c|}
\hline Parameter & SIBM & hIBM \\
\hline \multicolumn{3}{|l|}{ I. Clinical hallmarks } \\
\hline Age at onset & $\begin{array}{l}\text { Late-onset (most cases after the fifth to sixth } \\
\text { decade of life) }\end{array}$ & $\begin{array}{c}\text { Earlier-onset than sIBM (most cases } \\
\text { varying from the third to fifth decade } \\
\text { of life) }\end{array}$ \\
\hline Male-to-female ratio & $3: 1$ & $1: 1$ (AD and AR cases) \\
\hline $\begin{array}{l}\text { Pattern of muscle } \\
\text { involvement }\end{array}$ & $\begin{array}{c}\text { Quadriceps and asymmetric distal arm and finger } \\
\text { flexor weakness (mainly nondominant side); } \\
\text { dysphagia (late); rare facial and extrinsic ocular } \\
\text { muscle groups involvement }\end{array}$ & $\begin{array}{l}\text { Variable; symmetric; distal myopathy; } \\
\text { limb-girdle muscle weakness; } \\
\text { scapuloperoneal myopathy; } \\
\text { ophthalmoparesis, ptosis; vocal cord } \\
\text { paresis; abdominal wall weakness }\end{array}$ \\
\hline Concurrent disorders & $\begin{array}{c}\text { Chronic viral infections (e.g. HIV/AIDS, hepatitis C, } \\
\text { HTLV-I), monoclonal gammopathies, chronic } \\
\text { lymphocytic leukemia, T cell large granular } \\
\text { lymphocytic leukemia, paraneoplastic, variable }\end{array}$ & $\begin{array}{c}\text { Amyotrophic lateral sclerosis, Paget } \\
\text { disease of bone, Frontotemporal lobar } \\
\text { degeneration }\end{array}$ \\
\hline
\end{tabular}

lymphocytic leukemia, paraneoplastic, variable common immunodeficiency, sarcoidosis, other connective tissue disorders

\section{Muscle pathology findings \\ General findings}

Inflammatory myopathy with rimmed vacuoles, aggregates and mitochondrial pathology; prominent endomysial infiltration by mononuclear cells, focal invasion of non-necrotic muscle fibers by CD8+ T cells and macrophages; MHC-I expression on surface of muscle fibers

\section{Specific findings}

\section{Laboratorial findings}

\section{Biological markers}

Muscle MRI
Rimmed vacuoles with congophilic positive inclusions and granular material in aggregates

(e.g. desmin, beta-amyloid, clusterin, betasynuclein, beta-tubulin, gelsolin, Tau phosphorylated, TDP-43, SQSTM1, presenilin-1, apolipoprotein-B and ubiquitin); non-vacuolated aggregates stain with LC-3 and SMI-31 antibody; increased number of COX negative and SDH positive muscle fibers for age; mononuclear endomisial foci with CD20 positive cells in chronic lymphocytic leukemia (reports)

Positive anti-cN1A antibodies (up to $75 \%$ of cases); serum CK raised less than 10-15 times de ULN or normal;

Specific HLA alleles association in familial IBM (e.g. DRB1*0301/0302, DR15(2)/4 (DRB1*1502/0405)) or SIBM (e.g. DRB1*0101/0202, DQB1*0201); DQ2 haplotype in early-onset cases Involvement of flexor digitorum profundus in the arms and marked compromise of the lower leg

(mainly the medial head of the gastrocnemius) and the anterior muscles of the thigh (with relative sparing of the rectus femoris)
Unspecific chronic myopathic findings with rimmed vacuoles (rarely mild and scarce lymphomonocyte infiltrates)
Each genetic subtype with specific testing for antibody expression in the muscle fiber and their coupled proteins

(e.g. VCP/p97, SQSTM1/p62); no congophilic inclusions; rarely without vacuoles and with mitochondrial myopathic findings
Specific genetic testing (e.g. GNE, VCP, MYH2, SQSTM1, HNRPA2B1, HNRNPA1);

no serum specific biochemical markers

GNE myopathy: quadriceps-sparing (mainly vastus lateralis) in late stages, and biceps femoris short head, gluteus minimus, tibialis anterior, extensor hallucis, soleus and gastrocnemius medialis in early phases; $V C P$ myopathy: widespread changes with patchy distribution; $M Y H 2$ myopathy: marked involvement of the medial gastrocnemius, semitendinosus, gracilis and vastus lateralis
IV. Therapeutic aspects

Immunoglobulin (IV)

Bimagrumab BYM338 and other immunosuppressive therapies

AD: autosomal dominant; AR: autosomal recessive; CK: creatine kinase; COX: cytochrome oxidase; IV intravenous; SDH: succinate dehydrogenase; ULN: upper limit value of normality. 
Despite the genetic and pathophysiological heterogeneity associated with hIBM, it is a common characteristic for all subtypes the adult-onset of slowly progressive distal myopathy mainly at feet dorsiflexion, evolving later to proximal appendicular and axial (paravertebral) muscle groups, in association with rimmed vacuoles and filamentous cytoplasmic inclusions in muscle biopsy. Distal upper limb weakness occurs mainly in deep finger and forefinger flexors muscle groups. There is no marked facial involvement as it occurs in advanced stages of sIBM patients over 50 years. In hIBM, there has been no cases with positive serum anti-cN1A antibodies (cytosolic anti-5'nucleotidase $1 \mathrm{~A}$ ), which are found in up to $70 \%$ of sIBM cases. However, serum creatine kinase (CK) elevations are commonly observed, but generally mildly (less than 10 times the upper limit of normality) or even with normal values. Regarding neurophysiological studies, in hIBM and sIBM, chronic and active myopathic and neurogenic findings are frequently found concomitantly ${ }^{1,22}$.

1. Nonaka distal myopathy with rimmed vacuoles

Typical hIBM (MIM \#605820) or Nonaka distal myopathy associated with the GNE gene (9p13.3) is characterized by the presence of autosomal recessive progressive myopathy starting in the third to fourth decade of life, first distally and symmetrically in the legs and then evolving with moderate to severe compromise of the 
proximal lower limb muscle groups and the Iliopsoas, but sparing the quadriceps femoris (the so-called "quadriceps sparing myopathy"). Rare variants with facial and quadriceps femoris involvement and minor distal myopathy have also been described. Cases have been more commonly described in some populations, such as Iranian jews, Japanese, Palestinian and Middle East muslim. Despite its neurometabolic dysfunction of sialic acid biosynthesis, the replacement of such acid has not disclosed significant clinical and functional evidence of improvement in patients with hIBM. It has not been established also the reason there is no multisystem involvement in such disorder as defective enzyme expression also occurs in central nervous system and other systems. Some authors still consider GNE-related myopathy mainly as a distal myopathy, thus maintaining the use of its former designation as Nonaka distal myopathy. A key differential diagnosis in rapidly progressive phenotypes is represented by Autosomal Dominant Myopathy with Early Respiratory Failure (ADMERF/HMERF) or Edstrom myopathy, a TTN-related distal myopathy, currently classified in the myofibrillar myopathy group, presenting with symmetric distal and proximal involvement of the lower limbs, mainly of the anterior tibial group, and early progressive respiratory failure and cardiac conduction block. Allelic disorder to GNE includes autosomal dominant sialuria (French type) 4,12,14,23. There is no expectancy in such hIBM presentations of benefit with Bimagrumab monoclonal antibody or other imunossupressive agents, previously studied for sIBM ${ }^{24}$. 
2.Inclusion body myopathy with early-onset Paget disease of bone with or without Frontotemporal Dementia type 1 (IBMPFD1)

IBMPFD1 (MIM \# 167320) associated with VCP (9p13.3) gene mutations is characterized by a wide and complex autosomal dominant spectrum of neurodegenerative disorders with incomplete penetrance. Clinical picture (Figure 3 ) is dominated by a myopathic phenotype starting between the third and seventh decade of life in a limb-girdle proximal pattern of involvement with typical VCP-positive inclusion bodies on muscle biopsy, osteolytic and sclerotic bone lesions diagnostic of early-onset Paget disease of bone (mainly in the spine, hip and skull), and one third of patients with frontotemporal lobar degeneration with early frontotemporal atrophy on neuroimaging studies. A pure myopathic phenotype with mild CK elevation and proximal and distal involvement is also eventually found. Atypical presentations with parkinsonism, dystonia, sensorimotor polyneuropathy and cataracts have rarely been described. Muscle MR imaging shows diffuse widespread fatty degeneration involving most thigh muscle groups and axial musculature. There is typical genotype-phenotype correlation in such cases, including the R155C mutation which gives rise to the most severe and earlier myopathic phenotypes and to earlier presentations of Paget disease of bone. Allelic disorders include familial ALS type 14, CharcotMarie-Tooth type $2 Y$, and hereditary spastic paraparesis ${ }^{12,17}$. 
Figure 3. Clinical examination findings in a patient with $V C P$ gene mutation. Examination showing mild tenar hypotrophy $(A)$, fist sign resulting from finger flexor muscle group weakness (B), marked atrophy of medial forearm muscle groups (C), and severe bilateral amyotrophy of the quadriceps femoris muscle, more severe in the left thigh (D). Source: first author own archive (reproduced with patient's permission and informed consent).

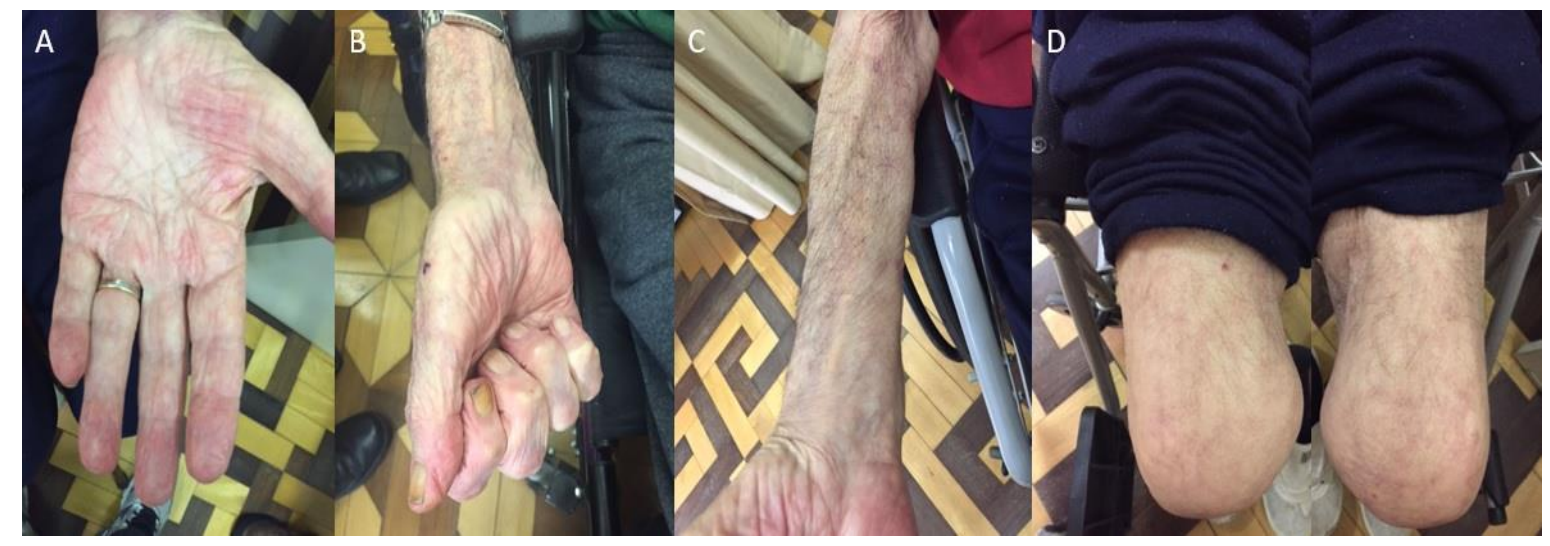

3.Inclusion body myopathy with early-onset Paget disease of bone with or without Frontotemporal Dementia type 2 (IBMPFD2)

IBMPFD2 (MIM \#615422) associated with HNRPA2B1 gene (7p15.2) mutations is characterized by autosomal dominant hereditary myopathy with scapuloperoneal phenotype starting in the third to fourth decades of life and Paget disease of bone involving the long bones, and eventually evolving with lower motor neuron disease, frontotemporal lobar degeneration and mild CK elevation. Rimmed vacuoles and high degree of nuclear centralization are frequently found in muscle biopsy ${ }^{12,16}$. Due to the rarity of this condition, specific muscle MR imaging findings are yet unknown. This genetic subtype seems more uncommon and rarely found when compared to VCP-related hIBM. 
4.Inclusion body myopathy with early-onset Paget disease of bone with or without Frontotemporal Dementia type 3 (IBMPFD3)

IBMPFD3 (MIM \#615424) associated with HNRNPA1 gene (12q13.13) mutations is characterized by autosomal dominant chronic hereditary myopathy starting in the fourth to fifth decade of life with slowly progressive limb-girdle phenotype and severe involvement of Iliopsoas and abdominal wall muscle groups with mild serum CK levels and mild to moderate serum phosphatase alkaline levels with Paget disease of bone, mainly found in the epiphyseal portion of the femur and in the lumbar vertebral bodies. Allelic condition includes familial ALS type 20 and rarely familial Flail-arm syndrome ${ }^{12,16}$. As it occurs with IBMPFD2, this hIBM genetic subtype represents a rare cause of hIBM when compared with VCP gene mutations, however without marked clinical association with FTD.

5.Myopathy with congenital joint contractures, ophthalmoplegia, and rimmed vacuoles

Proximal myopathy with congenital joint contractures, external ophthalmoplegia, and rimmed vacuoles (MYPOP; MIM \#605637) is associated with MYH2 (17p13.1) gene mutations and characterized by slowly progressive or nonprogressive autosomal dominant myopathy starting in infancy, presenting mainly with muscle atrophy of the 
quadriceps femoris and pectoralis major and minor muscles. Variable involvement with eyelid ptosis, ophthalmoparesis and scoliosis is also described. Muscle biopsy discloses type 1 predominance with type 2A muscle atrophy and high degree of nuclear centralization and commonly the finding of rimmed vacuoles in affected muscle groups. In cases with marked eyelid ptosis and ophthalmoplegia, mitochondrial myopathy makes the most important differential diagnosis, being frequently misdiagnosed as chronic progressive external ophthalmoplegia. Rare familial presentations with autosomal recessive inheritance pattern have also been described $^{12,15}$.

\section{SQSTM1-related hIBM}

hIBM has also been described in association with heterozygous mutations in the SQSTM1 gene (5q35.3; sequestosome 1 ), coding the p62 protein (sequestosome 1 ), involved in NFKB1 signaling pathway, neuronal apoptosis, nuclear transcription regulation and mainly in ubiquitinmediated autophagy by shuttling aggregated and ubiquitinated proteins to the forming autophagosome. Most cases of hIBM related to SQSTM1 gene mutations occurred in the context of an autosomal dominant multisystem familial proteinopathy, involving IBM, FTD, Paget disease of bone and ALS. However, splice site mutation in SQSTM1 has been described in patients from a United States family with autosomal dominant late-onset distal lower extremity 
myopathy with rimmed vacuoles with TDP-43 and SQSTM1 positive inclusions. Allelic disorders include Paget disease of bone type 3 and FTD with ALS type $3^{18,25,26}$.

\section{hIBM: a key clinical and genetic model to understand neurodegenerative processes}

As genetic and metabolic basis related to hIBM were being established, different studies involving intraneuronal and muscle intracellular microenvironment have been carried out and revealed a complex range of pathological mechanisms. Thus, disorders related to the biosynthesis of sialic acid in the GNE gene mutations with deficiency of UDP$\mathrm{N}$-acetylglucosamine 2-epimerase with reduction of posttranslational changes in glycoproteins and glycolipids proved a key mechanism in the main presentation of hIBM in clinical practice with dysfunction of adhesion molecules (notably NCAM) and surface and nuclear glycoproteins (alphadystroglycan and neprilysin-1, respectively) ${ }^{4,12}$. However, it is not yet understood why such enzyme deficiencies give rise to a marked isolated myopathic phenotype without multisystem or neurodegenerative associated disorders.

There is marked pathophysiological overlap between genetic mechanisms common to hIBM subtypes and familial ALS involving multisystem proteinopathies and intracytoplasmic system of ubiquitin-proteosome networks ${ }^{16,27,28}$. Thereby, $V C P$ gene mutations result from complex dysfunctions in the biogenesis of the Golgi apparatus, ubiquitin-proteosome system, protein 
degradation of external mitochondrial membrane, establishment and maturation of the autophagosome, clathrin-mediated membrane endocytosis and cell cycle regulation ${ }^{29}$.

Dysfunctions involving the ribonucleoproteins $A 1$ and B1 originate intracellular defects related to splicing and processing of messenger preRNA and interaction with RNA polymerase $\mathrm{II}^{29}$, being, thus, a pathophysiological mechanism not restricted to skeletal muscle groups or to the central nervous system. Regarding other hIBM subtypes, it has not been well-defined if mutations in the gene coding heavy myosin chain IIa could be associated with nonmyopathic complex neurodegenerative spectrum of disorders or with multisystem proteinopathy phenotype ${ }^{15}$. This complex multisystem disorders have also been linked to other genes involved with similar pathophysiological mechanisms, including OPTN, DNAJB6 and HNRNPDL, thus, disclosing a complex network of proteins involved in intracellular protein homeostasis and related with the same mechanisms previously described in ALS, FTLD and other degenerative disorders $3,27,29,30$.

There is a lot of expectancy that the knowledge related to hIBM etiopathogenesis can represent the basis to understand properly the mechanisms of IBM and other clinically significant neuromuscular and neurodegenerative disorders (including ALS, parkinsonian syndromes and frontotemporal lobar degeneration) and systemic diseases (such as Paget disease of bone), as well as the foundation in 
the development of common specific therapeutic modalities for such multisystem disorders ${ }^{29,30}$.

\section{CONCLUSIONS}

hIBM represents a rare and heterogeneous hereditary myopathy group, certainly underdiagnosed, and associated with complex neurogenetic and pathophysiological dysfunctions with proper clinical and pathological hallmarks depending on the metabolic or degenerative basis involved. Previously considered merely an extension of sporadic IBM, hIBM is distinct in different aspects (Table 2) and represents a widening and noteworthy group of hereditary vacuolar myopathies, which makes them difficult to classify as a group, but also acts as a prototype of broadening neurogenetic spectrum of clinical conditions and offers a great opportunity to provide proper development of targeted therapies based in molecular and genetic approaches.

\section{REFERENCES}

1.Dalakas MC. Inflammatory muscle diseases. $\mathrm{N}$ Engl J Med 2015;372:1734-47. https://doi.org/10.1056/NEJMra1402225

2.Dimachkie MM, Barohn RJ. Inclusion body myositis. Neurol Clin 2014;32:629-46. https://doi.org/10.1016/j.ncl.2014.04.001

3.Askanas V, Engel WK, Nogalska A. Sporadic inclusion-body myositis: a degenerative muscle disease associated with aging, impaired muscle protein homeostasis and abnormal mitophagy. Biochim Biophys Acta 2015;1852:633-43. https://doi.org/10.1016/j.bbadis.2014.09.005 4. Mastaglia FL, Needham M. Inclusion body myositis: a review of clinical and genetic aspects, diagnostic criteria and therapeutic approaches. J Clin Neurosci 2015;22:6-13. https://doi.org/10.1016/j.jocn.2014.09.012 
5. Machado P, Brady S, Hanna MG. Update in inclusion body myositis. Curr Opin Rheumatol 2013;25:763-71. https://doi.org/10.1097/01.bor.0000434671.77891.9a

6.Amato AA, Barohn RJ. Inclusion body myositis: old and new concepts. J Neurol Neurosurg Psychiatry 2009;80:1186-93. https://doi.org/10.1136/innp.2009.173823

7.Saltychev M, Mikkelsson M, Laimi K. Medication of inclusion body myositis: a systematic review. Acta Neurol Scand 2016;13397-102. https://doi.org/10.1111/ane.12455

8. Machado PM, Ahmed M, Brady S, Gang Q, Healy E, Morrow JM, et al. Ongoing developments in sporadic inclusion body myositis. Curr Rheumatol Rep 2014;16:477. https://doi.org/10.1007/s11926-0140477-9

9.Solorzano GE, Phillips II LH. Inclusion body myositis: diagnosis, pathogenesis, and treatment options. Rheum Dis Clin N Am 2011;37:173-83. https://doi.org/10.1016/j.rdc.2011.01.003

10.Catalán M, Selva-O'Callaghan A, Grau JM. Diagnosis and classification of sporadic inclusion body myositis (sIBM). Autoimmun Rev 2014;13:363-6. https://doi.org/10.1016/j.autrev.2014.01.016 11. Needham M, Mastaglia FL. Sporadic inclusion body myositis: a review of recent clinical advances and current approaches to diagnosis and treatment. Clin Neurophysiol 2016;127:1764-73. https://doi.org/10.1016/j.clinph.2015.12.011

12. Needham M, Mastaglia FM, Garlepp MJ. Genetics of inclusion-body myositis. Muscle Nerve 2007;35:549-61.

https://doi.org/10.1002/mus.20766

13. Benarroch L, Bonne G, Rivier F, Hamroun D. The 2020 version of the gene table of monogenic neuromuscular disorders (nuclear genome). Neuromuscul Disord 2019;29:980-1018. https://doi.org/10.1016/j.nmd.2019.10.010

14.Nishino I, Carrillo-Carrasco N, Argov Z. GNE myopathy: current update and future therapy. J Neurol Neurosurg Psychiatry 2015;86:385-92. https://doi.org/10.1136/jnnp-2013-307051

15.Tajsharghi H, Thornell LE, Darin N, Martinsson T, Kyllerman M, Wahlström J, et al. Myosin heavy chain IIa gene mutation E706K is pathogenic and its expression increases with age. Neurology 2002;58:780-6. https://doi.org/10.1212/wnl.58.5.780

16. Kim HJ, Kim NC, Wang YD, Scarborough EA, Moore J, Diaz Z, et al. Mutations in prion-like domains in hnRNPA2B1 and hnRNPA1 cause multisystem proteinopathy and ALS. Nature 2013;495:467-73. https://doi.org/10.1038/nature11922

17. Kazamel M, Sorenson EJ, McEvoy KM, Jones LK Jr, Leep-Hunderfund AN, Mauermann ML, et al. Clinical spectrum of Valosin Containing Protein (VCP)-opathy. Muscle Nerve 2016;54:94-9. https://doi.org/10.1002/mus.24980

18.Gang Q, Bettencourt C, Brady S, Holton JL, Pittman AM, Hughes D, et al. SQSTM1 and VCP mutations in a series of 205 inclusion body myositis cases. Muscle Nerve 2015;52:S2.

http://hdl.handle.net/1854/LU-6940782 
19.Krause S. Insights into muscle degeneration from heritable inclusion body myopathies. Front Aging Neurosci 2015;7:13. https://doi.org/10.3389/fnagi.2015.00013

20.Feit $H$, Silbergleit A, Schneider LB, Gutierrez JA, Fitoussi RP, Réyes $C$, et al. Vocal cord and pharyngeal weakness with autosomal dominant distal myopathy: clinical description and gene localization to 5q31. Am J Hum Genet 1998;63:1732-42. https://doi.org/10.1086/302166

21.Broccolini AB, Gidaro T, Morosetti R, Mirabella M. Hereditary inclusion-body myopathy: clues on pathogenesis and possible therapy. Muscle Nerve 2009;40:340-9. https://doi.org/10.1002/mus.21385

22. Das B, Goyal MK, Bhatkar SR, Vinny PW, Modi M, Lal V, et al. Hereditary inclusion body myopathy: a myopathy with unique topography of weakness, yet frequently misdiagnosed: case series and review of literature. Ann Indian Acad Neurol 2016;19:119-22. https://doi.org/10.4103/0972-2327.167709

23. Malicdan MC, Noguchi S, Nishino I. A preclinical trial of sialic acid metabolites on distal myopathy with rimmed vacuoles/hereditary inclusion body myopathy, a sugar-deficient myopathy: a review. Ther Adv Neurol Disord 2010;3:127-35. https://doi.org/10.1177/1756285609359546

24.Amato AA, Sivakumar K, Goyal N, David WS, Salajegheh M, Praestgaard J, et al. Treatment of sporadic inclusion body myositis with bimagrumab. Neurology 2014;83:2239-46. https://doi.org/10.1212/WNL.0000000000001070

25.Gang Q, Bettencourt C, Machado PM, Brady S, Holton JL, Pittman AM, et al. Rare variants in SQSTM1 and VCP genes and risk of sporadic inclusion body myositis. Neuropathol Aging 2016;47:218. https://doi.org/10.1016/j. neurobiolaging.2016.07.024

26. Bucelli RC, Arhzaouy K, Pestronk A, Pittman SK, Rojas L, Sue CM, et al. SQSTM1 splice site mutation in distal myopathy with rimmed vacuoles. Neurology 2015;85:665-74.

https://doi.org/10.1212/WNL.0000000000001864

27. Takada LT. The genetics of monogenic frontotemporal dementia. Dement Neuropsychol 2015;9:219-29. https://doi.org/10.1590/198057642015DN93000003

28. Benatar M, Wuu J, Fernandez C, Weihl CC, Katzen H, Steele J, et al. Motor neuron involvement in multisystem proteinopathy: implications for ALS. Neurology 2013;80:1874-80.

https://doi.org/10.1212/WNL.0b013e3182929fc3

29.Souza PV, Pinto WB, Chieia MA, Oliveira AS. Clinical and genetic basis of familial amyotrophic lateral sclerosis. Arq Neuropsiquiatr 2015;73:1026-37. https://doi.org/10.1590/0004-282X20150161

30.Taylor JP. Multisystem proteinopathy: intersecting genetics in muscle, bone, and brain degeneration. Neurology 2015;85:658-60. https://doi.org/10.1212/WNL.0000000000001862 